\title{
Total-English Teaching Practice of the Circuit Theory for Undergraduate International Students
}

\author{
Shi-Hong WU*, Li-Di WANG, Yu-Qiu SONG, Jian E, Ping YANG, Nan-Nan ZHANG \\ Information and Electrical Engineering College, \\ Shenyang Agricultural University \\ Shenyang, China \\ shihong.1@163.com
}

\begin{abstract}
With the continuous expansion of the scale of internationalization of higher education in China, English teaching for international students has become an important way of education for international students and an advanced teaching mode in line with international standards. Based on the problems existing in the course of circuit theory in the process of teaching, how to choose appropriate teaching materials, the appropriate teaching contents, appropriate teaching management, proper teaching methods and teaching practice is studied in detail. The total-English teaching experience of the author's circuit theory course is summarized and puts forward a new English teaching mode and practice method, which improves the quality of totalEnglish teaching of the circuit theory for international students. It is hoped that it can be used as a reference of other totalEnglish teaching courses for international students.
\end{abstract}

Keywords-undergraduate international students; circuit theory; total-english teaching; teaching practice

\section{INTRODUCTION}

With the further development of China's opening-up and the demand of One Belt and One Road, more and more foreign students go to China for further study ${ }^{[1]}$ In recent years, our university has carried out the education of international students mainly in African countries, which mainly include electrical engineering, mechanical engineering, agricultural engineering ,water conservancy engineering, civil engineering, animal medicine, international economy and trade and the major such as computer science and technology, as a result of the students language, education background, cultural background, ideology differences and living habits, which makes the teaching of international students face some difficulties. In this paper, based on author's experience in teaching circuit courses in total-English for many years, and combined with the learning characteristics of foreign students, the English teaching mode of circuit theory is preliminarily studied. The problems in teaching, including the selection of teaching materials and arrangement of teaching contents, teaching methods, the role of teachers, practical teaching and assessment methods are considered in this paper, and corresponding solutions are proposed to further improve the total-English teaching level and quality of circuit theory for international students.

This work was sponsored by the undergraduate teaching reform research project of education for general higher education in Liaoning Province in 2018 and the Education teaching research project of Shenyang Agricultural

University 2018

\section{THE PROBLEMS EXISTING IN THE TOTAL-ENGLISH TEACHING OF CIRCUIT THEORY FOR UNDERGRADUATE INTERNATIONAL STUDENTS}

\section{A. shortage of totally English teaching teachers}

Excellent teachers are the guarantee of course teaching quality, and also the key to improve the quality of talent training. Although international students in China are mainly from African and South Asian countries, with high English proficiency, some of them speak English with a local accent, and have great differences in the characteristics and expressions of standard American or British English with domestic teachers. In addition, the Chinese proficiency of foreign students is very low, and only a few simple everyday words, which can't guarantee smooth communication between teachers and students. It greatly affects the teaching process of circuit course and the learning enthusiasm of international students. Due to the shortage of English teaching faculties, the English teaching of professional courses puts forward higher teaching requirements for teachers. Teachers for total-English teaching should not only fully master the professional course knowledge, but also have strong English expression and communication skills, so as to ensure no language barriers in the total-English teaching process. At present, most teachers do not have long-term and systematic English listening and speaking training experience, and are often discouraged from teaching courses in total-English. As a result, it is common to have only one total-English teacher for a course, and reserve teachers are extremely scarce. In addition, some teachers tend to rely too much on PPT courseware, which makes them lifeless and lack sufficient teaching interaction and in-depth explanation, thus greatly affecting the teaching effect and quality and hardly arousing the interest of overseas students.

\section{B. The dated teaching concept in total-English teaching}

After several rounds of teaching, it is found that foreign students have strong self-learning ability, like to think independently, and are active in thinking and good at asking questions, which requires teachers to have good teaching interaction ability. For example, due to the teachers' laziness or inertia in adopting the traditional cramming teaching mode, international students tend to receive less professional knowledge. In addition, the teacher only pays attention to the classroom teaching effect but has neglected the student outside 
the classroom preview and the review. Due to language barriers and cultural differences, it is difficult for international students to communicate harmoniously with domestic students in the short term. At the same time, the lack of total-English review resources outside the classroom seriously affects the teaching quality ${ }^{[2]}$.

\section{Not paying attention to the course preview and review after class}

Foreign students lack the habit of taking notes in class and have no proper original English textbooks. A certain number of foreign students do not study hard, do not bring books and notebooks in class and some students even wear headphones to listen to music. At the same time, the phenomenon of being late and leaving early occurs from time to time. They don't pay attention to preview and review at all, and don't want to spend time on it. Therefore, they often forget what they have learned some time ago after learning the new and it is difficult for them to organically connect the knowledge points they have learned. They can delay the homework they have been assigned, and it is difficult to achieve the desired effect.

\section{Unreasonable selection and use of English textbooks}

No textbook is like water without a source. Teaching is an educational behavior in which teachers exert influence on students through the medium of textbooks and students learn knowledge and skills through textbooks under the influence of teachers. High-quality English textbooks are helpful to eliminate the misunderstanding of professional course knowledge caused by language barriers in the process of English teaching and are an important objective factor to ensure the quality of teaching. Therefore, good teaching material is the premise of guaranteeing teaching quality and teaching efficiency. However, at present, many colleges and universities do not have a standard for the selection of English textbooks. It is basically chosen by teachers according to their own teaching experience and preference. ${ }^{[3]}$ Most colleges and universities mainly through the way of introducing foreign original English teaching materials to carry out the professional English teaching, but the content arrangement of original English teaching material and teaching focus is not necessarily completely agree with the strategy of fostering talents in universities and colleges in China and the teaching requirements, section or a lack of corresponding experimental teaching conditions, therefore, teacher needs to adjust the teaching material content moderately. However, some teachers do not understand and study the quoted English textbooks well enough, so it is difficult to use them scientifically and reasonably ${ }^{[4]}$ How to choose a suitable textbook in English and how to present the teaching content of the high-quality textbook to foreign students in the process of teaching in English is both a problem faced by teachers and an urgent problem to be solved.

\section{E. Problems in circuit theory of experimental course teaching for international students}

Firstly, the lack of suitable textbooks in English. We tried to use Chinese textbooks, but foreign students said they only knew a little everyday language, and they could not understand
Chinese textbooks at all. In addition, although English is not necessarily the native language of foreign students, most of them speak English better than Chinese. However, at present, it is difficult to find textbooks in English that meet our requirements for the teaching for foreign students.

Secondly, doing circuit experiments lacks patience and care. Compared with domestic students, overseas students are lively and energetic, but they are not patient enough when doing circuit experiments. They even don't preview. Some students often start the experiment in a hurry before the end of the teacher's explanation. Some don't do it themselves and wait for the teacher to make a demonstration before they do it. Most of the time, only one person in a group is doing it. So you can imagine that the experiment didn't work very well.

\section{TEACHING RESEARCH AND PRACTICE OF CIRCUIT THEORY IN TOTAL-ENGLISH}

\section{A. Strengthening the construction of teaching staff}

Our university attaches great importance to the cultivation and echelon construction of the teaching staff of professional courses of total-English teaching, and has formulated corresponding policies and guarantee mechanisms to employ experienced foreign teachers or teachers with foreign teaching experience and experienced teaching experience in our university to train and demonstrate the total-English teaching teachers in order to improve classroom control ability in the total-English teaching process. Our university encourages teachers to carry out bilingual teaching to write English teaching plans and deeply analyze English teaching materials, and encourages teachers to write English teaching materials with independent intellectual copyright, so that teachers can gradually become total-English teaching teachers from bilingual teaching teachers. At the same time, our university has also raised a large amount of funds to actively support outstanding young and middle-aged teachers to study and visit abroad, and actively participate in the teaching process of foreign universities and colleges, so as to master advanced English teaching methods and enhance oral communication ability. More than 100 teachers have been sent to study abroad in three years. Thus the English teaching level of teachers is greatly improved. In addition, total-English teachers should observe students emotional changes, special circumstances of students in attendance or classroom performance and pay more attention to ask them in time. Teachers strive to find out students' discomfort and depression caused by various reasons in time and help them overcome these discomfort.

In a word, teachers should not only impart knowledge to foreign students but also become their good friends in China. Only when they accept China in their hearts and fall in love with China, can they live and study in China with a better and more positive attitude ${ }^{[5]}$.

\section{B. Teaching concept and teaching method of circuit theory is constantly improved in English in teaching practice}

In the teaching process, the small-class teaching mode should be fully utilized and the principle of taking international students as the teaching center should be embodied. The 
inspiring and interactive teaching methods should be used to stimulate the interest of international students in learning circuit theory and induce students to actively participate in the classroom teaching process. Teachers should elaborate courseware imparts some difficult problems to students through animation with pictures and texts, so as to improve the effect of students' having class ${ }^{[6]}$. The problem of students with low enthusiasm for active learning can be solved by writing an English version of the exercise book and send it to them and ask them hand in assignments regularly and answer common questions uniformly, which Further deepen the students' understanding of the theory. At the same time, total- English teachers should take the initiative to care for international students. Adequate communication and exchange outside the classroom can not only make each other familiar with each other's English expressions and pronunciation habits, but also help improve the teaching effect. The instructors may also set up a WeChat group or online course for international students in his/her class, put related courses in English learning resources such as English teaching video and virtual simulation teaching software and so on provided to them,which will facilitate their self-study after class, further facilitate the communication channels between foreign students and teachers, and build a digital platform that provides all-round services for foreign students and teachers who teach in English.

\section{Strengthening the construction of teaching materials and extend the teaching process}

Our university makes use of the opportunity of teaching evaluation and international teaching certification, and takes active measures to revise or recompile English textbooks for professional courses on the basis of self-published bilingual textbooks. Our circuit teacher is a successful example. Not only did he become a total-English teaching teacher from a bilingual teacher naturally, but he also wrote a textbook on circuit theory in English published by Tsinghua University Press.

In terms of experimental teaching, the equipment and facilities of the laboratory of foreign universities and the circuit laboratory of our university are quite different, and the requirements for teaching and the actual ability of foreign students are also different. Although there are teaching materials of circuit theory experiment in foreign countries, there are few even photocopied ones in China. Therefore, it is impossible for us to directly use the corresponding English experimental teaching materials in foreign universities. On the basis of referring to foreign textbooks and summing up years of experience in Chinese experimental teaching of circuit theory, and aiming at the characteristics of foreign students' learning, the Chinese version of circuit principle experimental instruction book compiled by our university has been compiled into an English experimental instruction book, which has been continuously improved in practical experimental teaching. In this way, the problem that there is no proper experimental teaching instruction is solved. In addition, our university encourage teachers with the experience of studying abroad to summarize the domestic and foreign advanced experience in teaching, multimedia and digital technology of the teaching material, to improve our country with independent intellectual property rights of the total-English teaching quality, gradually transit English teaching materials introduced from abroad to domestic high quality English teaching materials, which enhances the level of students in total-English teaching in China.

\section{Giving full play to the initiative of foreign students, implementing classified experimental teaching, and} improving the quality of experimental teaching

The circuit theory experiment is divided into verification experiment, design experiment and synthesis experiment. In the process of teaching, teachers should avoid infusion-style teaching and cultivate the students' active learning habits. The first stage of the experimental class is a verification experiment, which is mainly guided by teachers. After this, we asked the overseas students to do the design experiment. At this time, there was little guidance. We asked the overseas students to design the experiment circuit by themselves and complete all the data measurement, so as to cultivate their ability to think and operate the experiment independently. A group of two people was arranged to carry out the comprehensive experiment, on the one hand, it provides students with more hands-on opportunities to cultivate their ability to cooperate with each other. On the other hand, it can avoid the disadvantages of one person operating while others are looking on. In addition, in the process of doing experiments, we selected students with strong experimental ability as leaders to drive students with a poor practical ability to do experiments. Since it is easier for international students to communicate with each other, the teacher not only explains the circuit repeatedly but also makes the students with the strong practical ability and good experimental performance explain the circuit components and connection methods to the students with learning difficulties, so that the experimental teaching results are satisfactory.

\section{E. paying attention to the process assessment, and adopt the comprehensive evaluation method to reflect the real results of international students}

International students are communicative and keen on the teaching process, but they often pay less attention to the final examination. Therefore, a single final examination method cannot enhance the examination effect of foreign students. The assessment methods of total-English teaching courses for foreign students should be flexible and diverse, not only focusing on the assessment of teaching process, but also taking the form of periodic examinations or classroom quizzes to disassemble the whole textbook into relatively independent knowledge lines, which can strengthen the teaching effect and correct the disadvantages of some foreign students' sudden review in the final exams. With a small class of more than ten students, it is convenient to check the students' study. According to chapter of the test unit, after every chapter is finished, I will give each student prepare a piece of paper, and ask them to answer 2 or 3 basic typical circuit problems within 10 to 15 minutes in class to examine their grasp of this chapter, the result will be released in the next class, and point out errors that students often make in a timely manner. Quizzes will occupy a part of the overall grade in the form of the usual grades. 
The student's overall score consists of four parts: attendance, assignments, quizzes and final exam results, where, 10 points are for attendance, 30 points are for quizzes, 10 points are for homework and 50 points are for final exams. The ratio is 1:3:1:5. Only in this way, can we mobilize students' learning enthusiasm, fully reflect their real performance and level, and make an effective evaluation of their efforts.

\section{CONCLUSION}

The total-English teaching of circuit theory for undergraduate international students is still in its infancy in our university, and there are still many problems to be solved. Circuit theory is a very important basic course for engineering majors (especially electrical engineering majors). To further improve the teaching quality of circuit theory for foreign students is a major challenge for all teachers. The totalEnglish teaching experience of circuit theory for international students is summarized, the total-English teaching teachers' training, the teaching idea of teaching methods, teaching material selection, experiment teaching, students learning characteristics and student achievement evaluation of actual practice are discussed respectively in this paper to improve the teaching quality of circuit theory total- English teaching in our university.

\section{ACKNOWLEDGMENT}

This work was sponsored by the undergraduate teaching reform research project of education for general higher education in Liaoning Province in 2018 and the Education teaching research project of Shenyang Agricultural University 2018 and the authors are extremely grateful to the Education Department of Liaoning Province and Shenyang Agricultural University for funding this project under Grant Number 2018355 and 2018-36 respectively.

\section{REFERENCES}

[1] The ministry of education. 2012 national students in China concise statistical[reportEB/].2013http://www.moe.gov.cn/publicfiles/business/h tmlfiles/moe/s5987/201303/148379. html.

[2] Si Daowen, Li Juan, Zhou Hongxia. An investigation of managing foreign medical students and their study situation[J].Chinese higher medical education, 2015(1), pp.37-38.(In Chinese)

[3] Yang Ping. Exploration of establishing model professional basic courses taught in English in engineering universities[J]. HIGHER EDUCATION OF SCIENCES, 2016(6), pp.116-120(In Chinese)

[4] Lin Botao, Lin Qing, Pang Huiwen. Exploration and practice of material mechanics in petroleum engineering[J].University Education, 2016(1), pp.77-79.(In Chinese)

[5] Song Xiaoqing, Wei Huiping, Liu Yinghui. Factors affecting the quality of full-English teaching in cell biology for foreign students and solutions[J]. Journal of Hebei North University(social Science Edition), 2014(2), pp.114-116.(In Chinese)

[6] Mei Xinming, Xu Fucui, Wang Qiaoya. The teaching practice and experience of histology and embryology in English [J].SICHUAN JOURNAL OF ANATOMY, 2011(1), pp.64-65.(In Chinese) 